\title{
Long-run performance of firms emerging from financial distress: Empirical evidence from Malaysia
}

\author{
Abd Halim Ahmad* • Nur Adiana Hiau Abdullah • Kamarun Nisham Taufil Mohd \\ College of Business, Universiti Utara Malaysia, Sintok, Malaysia
}

Received: 2 January 2018

Revised: 25 April 2018

Accepted: 26 April 2018

\begin{abstract}
We examine the long-run performance of firms emerging from financial distress in Malaysia. The sample consists of 114 companies listed on the Bursa Malaysia stock exchange that emerged from a financially distressed classification between 2001 and 2014. We investigate whether post-distressed performance is similar to the performance of firms of equivalent size and book-to-market ratio. The results suggest that firms emerging from financial distress in Malaysia underperform when compared to the performance of firms similar in size and bookto-market ratio. This suggests that the post-restructuring performance of firms on the Bursa Malaysia stock exchange that have emerged from financial distress does not improve.
\end{abstract}

Keywords: long-run performance; Malaysia; buy-and-hold abnormal return; cumulative average abnormal return; financial distress

JEL Classification Codes: G14, G32, G34

\section{Introduction}

This study investigates the post-restructuring performance of restructured companies. It addresses whether the existing regulations governing companies in distress effectively improves the condition of financially distressed companies or simply helps poorly performing companies to survive. If the restructuring exercise is biased toward the continuation of unviable companies, poor performance will persist even after the companies emerge from the restructuring period. The efficiency of the Chapter 11 U.S. bankruptcy code has been extensively debated in the literature. Hotchkiss (1995) argues that Chapter 11 reorganization promotes the continuation of inefficient or unviable companies by providing these companies the opportunity to reorganize, which lead to "chronic inefficiencies" (Hotchkiss, 1995). In addition, Gilson (1997) postulates

\footnotetext{
* Corresponding author. E-mail: abd.halim@uum.edu.my.
}

Citation: Ahmad, A. H., Abdullah, N. A. H., and Taufil Mohd, K. N. (2018) Long-run performance of firms emerging from financial distress: Empirical evidence from Malaysia, Economics and Business Letters, 7(1), 4754. 
that the reorganization process delineated in Chapter 11 is substantially focused on facilitating the emergence of firms with high debt.

A considerable amount of research literature has investigated the post-bankruptcy performance of restructured companies, with mixed empirical findings. Several studies have revealed that post-bankruptcy performance is generally poor because of weak accounting performance, high debt ratios and the ongoing need for debt restructuring (Komera and Lukose, 2013; Gilson, 1997; Hotchkiss, 1995; Hotchkiss and Mooradian, 1997). On the other hand, the study by Eberhart et al. (1999) demonstrates that there are significant positive excess common stock returns for companies emerging from Chapter 11, as shown by the average abnormal returns, which range from $24.6 \%$ to $138.8 \%$ in the 200 days following emergence. Conversely, Alderson and Betker (1999) demonstrate that reorganized companies neither underperform nor overperform following Chapter 11 reorganization. More recent evidence offered by Jory and Madura (2010) supports a study by Alderson and Betker (1999) which revealed that the post-bankruptcy stock performance of reorganized companies is similar to the performance of companies similar in size and book-to-market ratio.

There are several motivations for conducting this study. Most of the previous empirical studies were almost exclusively based on failure cases in the United States, which are regulated under the United States bankruptcy legislation. The United States is, in fact, the most debtorfriendly bankruptcy regime in the Western world (Coelho, 2008; Altman \& Hotchkiss, 2006). As such, it would be interesting to extend the findings uncovered in the previous empirical studies on financial distress in Malaysia where the law is more creditor-oriented. Apart from the legal setting, there are major differences between the United States and Malaysia in terms of governance and institutional settings, suggesting that the US empirical evidence in this area may not be applicable to Malaysia. Claessens, Djankov and Klapper (2005) demonstrate that the diverse structure of bankruptcy laws is due to differences in institutional background. Similar to elsewhere in Asia, Malaysia has a high concentration of ownership where the mean shareholdings of the single largest shareholder are 31 percent and those of the five largest shareholders of companies are 62 percent (Haniffa \& Hudaib, 2006). Further evidence found by La Porta, Lopez-de-Silanes and Shleifer (1999) reveals that the United Kingdom, United States and Japan have low ownership concentration. Thus, using Malaysia as a context of study could provide us with an ideal setting and uncover further evidence about the behaviour of high ownership among large shareholders as compared to the dispersed ownership structure in the United States. This has led to studies of corporate failure which tend to be country-specific since the causes of corporate failure and the strategies undertaken during restructuring may differ according to the country context. Recently, Wang (2012) undertook a comparative study to examine the role of institutional factors (bankruptcy codes and judicial efficiency) in the decision to resolve bankruptcy through reorganization and liquidation, finding that the legal origin of the bankruptcy code is important for determining the choice of either reorganization or liquidation.

In Malaysia, financially distressed listed companies are governed by Practice Notes 17 (previously was Practice Notes 4) and Guidance Notes 3 to improve their financial condition in order to remain listed entities. Open questions remain pertaining to whether firms emerging from a financially distressed condition outperform when compared to their counterparts. Utilizing 114 firms emerging from financial distress that were listed on the Bursa Malaysia stock exchange from the period spanning 2001 to 2014, the empirical evidence suggests post-emergence declines among these companies over the three-year period following their emergence, irrespective of the methodological approach employed.

The organization of this study is as follows. Section 2 describes the data and methodology, and Section 3 discussing the empirical results. Section 4 concludes the study. 


\section{Data and methodology}

The search for financially distressed companies commences at the beginning of the Practice Notes 4 in February 2001 and continues through Practice Notes 17 and Amended Practice Notes 17 until 31 December 2014. Publicly listed companies' announcements regarding effective emergence dates are observed. As has been the case in previous studies, financial institutions and real estate and insurance companies have been excluded from the study, since the accounting presentations of their financial statements are significantly different from those in other sectors.

A sample of matching or control companies is constructed in accordance with each of the financially distressed companies that has emerged using specified firm characteristics. According to Barber and Lyon (1997), using the matching companies approach could eliminate new listing bias, rebalancing bias, and the skewness problem. In addition, it could generate wellspecified test statistics in all of the situations being considered, which eliminates bias in the residuals that may affect abnormal returns in the holding period (Campbell et al., 2009). For each of the financially distressed companies, based on the similar trading avenue (either Main Market or ACE Market), a pool of potential matching companies is sought, with market size (market capitalization) closest to that of the distressed company selected according to the market size of matching companies. For market size and market-to-book value ${ }^{1}$ matching size, the Euclidean distance procedure is used to select the closest match to that of the distressed company. This could be done by transforming the size and market-to-book value into z-scores by subtracting the mean and dividing by the standard deviation. The closest matching firm is defined as the firm with the smallest Euclidean distance to the sample firm in the two-dimensional space of z-scores. The next closest Euclidean distance matching firm is selected if it is delisted before the three-year period.

The Euclidean distance (ED) is calculated using the following equation:

$$
\mathrm{ED}=\left\|\left(\frac{M V_{p}}{\sum_{i=1}^{n} M V_{i}}-\frac{M V_{i}}{\sum_{i=1}^{n} M V_{i}}\right)^{2}+\left(\frac{M T B V_{p}}{\sum_{i=1}^{n} M T B V_{i}}-\frac{M T B V_{i}}{\sum_{i=1}^{n} M T B V_{i}}\right)^{2}\right\|
$$

where $\mathrm{MV}_{p}$ : market value of emerged firm $p$ in the month prior to the month of emergence; $\mathrm{MV}_{i}$ : market value of firm $i$; $\mathrm{MTBV}_{p}$ : market-to-book value of firm emerged $p$ in the month prior to the month of emergence; and $\mathrm{MTBV}_{i}$ : market-to-book value of firm $i$.

The analysis of share price performance starts on the day of the company's emergence from the Practice Notes or Guidance Note up to three years from the emergence date. If the company is under trading suspension, the analysis begins from the first day of trading after the suspension is lifted due to the emergence from the Practice Notes or Guidance Note. The event month [t=0] for this study is set as the end of the month in which outcomes of distress are announced. A number of methods are used to ensure that consistent and robust results are obtained throughout the analysis since the results can be influenced by the methodology (Gompers and Lerner, 2003). Without hesitation to compare the weakness of the methods, standard long-run event study methods - namely, cumulative average abnormal returns (CAARs) - and buy-and-hold abnormal returns (BHARs) are employed to make inferences regarding the long-run share performance of the restructured companies over the three- year period.

\footnotetext{
${ }^{1}$ Market-to-book value is calculated as the company's market value divided by the book value of the companies at the end of the month of the emergence outcomes announcement.
} 


\subsection{Cumulative average abnormal returns (CAARs)}

The abnormal return of company $i$ in the event month $t$ is computed as follows:

$$
A R_{i, t}=R_{i, t}-R_{b, t}
$$

where $R_{i, t}$ is the raw return of company $i$ in the event month $t$ and $R_{b, t}$ is the raw return of matching company $b$ in the event month $t$.

The average abnormal return for month $t$ is computed using the following equation:

$$
A A R_{t}=\sum_{i=1}^{N} A R_{i, t} / N_{t}
$$

The CAR (cumulative abnormal return) from $\tau_{1}$ to $\tau_{2}$ is calculated by cumulating the average abnormal returns for 36 months after the emergence date.

$$
C A R_{i, \tau_{1}-\tau_{2}}=\sum_{\tau_{1}}^{\tau_{2}} A A R_{i, t}
$$

The cumulative average abnormal return (CAAR) from period $\tau_{1}$ to $\tau_{2}$ can be obtained by the following equation:

$$
C A A R_{\tau_{1}-\tau_{2}}=\sum_{i=1}^{N} \frac{C A R_{i, \tau_{1}-\tau_{2}}}{N_{\tau_{1}-\tau_{2}}}
$$

The $t$-statistics on the significance of CAAR are computed as follows:

$$
t=C A A R_{1, \tau_{1}-\tau_{2}} /\left(\sigma_{\tau_{1}-\tau_{2}} / \sqrt{N_{\tau_{1}-\tau_{2}}}\right)
$$

where $N_{\tau_{1}-\tau_{2}}$ is the number of companies trading during period $\tau_{1}$ to $\tau_{2}$ and $\sigma_{\tau_{1}-\tau_{2}}$ is specified as

$$
\sigma_{\tau_{1}-\tau_{2}}=\left[\frac{\sum_{i=1}^{N_{x-y}}\left(C A R_{i, \tau_{1}-\tau_{2}}-C A A R_{\tau_{1}-\tau_{2}}\right)^{2}}{N_{\tau_{1}-\tau_{2}}}\right]^{1 / 2}
$$

is the cross-sectional standard deviation of abnormal return on event month $t$.

\subsection{Buy-and-hold abnormal returns (BHARs)}

The buy-and-hold abnormal returns are computed as follows:

$$
\left.\operatorname{BHAR}_{i}\left(\tau_{1}, \tau_{2}\right)=\prod_{t=\tau_{1}}^{\tau_{2}}\left(1+R_{i, t}\right)-\prod_{t=\tau_{1}}^{\tau_{2}}\left[1+R_{b, t}\right)\right]
$$

where $\operatorname{BHAR}_{i}\left(\tau_{1}, \tau_{2}\right)$ is the buy-and-hold abnormal return for company $i$ from time $\tau_{1}$ to $\tau_{2}, R_{i, t}$ is the raw return for company $i$ at time $t$, and $R_{b, t}$ is the return from a matching or control company at time $t$. Cross-sectional average BHARs are then calculated as follows:

$$
\overline{\operatorname{BHAR}\left(\tau_{1}, \tau_{2}\right)}=\frac{1}{N} \sum_{i=1}^{n} \operatorname{BHAR}_{i}\left(\tau_{1}, \tau_{2}\right)
$$


where $B H A R_{i}\left(\tau_{1}, \tau_{2}\right)$ is the buy-and-hold abnormal return of company $i$ from period $\tau_{1}$ to $\tau_{2}$, and $\mathrm{N}$ is the number of companies with valid BHAR over time period $\tau_{1}$ to $\tau_{2}$.

Drawing on the work of Loughran and Ritter (2000), the present analysis emphasizes the equally weighted return. This is due to the fact that value-weighted returns can overstate standard errors, leading to low power in detecting abnormal performance. Two procedures are employed to determine the statistical significance of the mean buy-and-hold abnormal returns. First, standard cross-sectional t-test statistics (similar to CAAR analysis in the previous section) are utilized, and second, the bootstrapped skewness-adjusted return t-statistics are employed. The bootstrapped skewness-adjusted t-statistics are specified as follows:

$$
t_{s a}=\sqrt{n}\left(S+\frac{1}{3} \hat{\gamma} S^{2}+\frac{1}{6 n} \hat{\gamma}\right)
$$

where $S=\frac{\overline{B H A R}_{t}}{\sigma\left(B H A R_{t}\right)}$ and $\hat{\gamma}=\frac{\sum_{i=1}^{n}\left(B H A R_{i, t}-\overline{B H A R}_{t}\right)^{3}}{n \sigma\left(B H A R_{t}\right)^{3}}$, where $\hat{\gamma}$ is the estimate of the coefficient of skewness and $\sqrt{n} S$ is the conventional $t$-statistics.

\section{Empirical results and discussion}

The industry classification of the sample is presented in Table 1. Industrial products and trading/services are the industries with the highest number of emerged companies which account for 25 percent respectively. The properties industry accounts for 14 percent of the sample, followed by construction (11\%), technology (10\%), consumer products industry (6\%), plantations (6\%), infrastructure project companies and hotels with two percent and one percent, respectively.

\subsection{Cumulative average abnormal returns (CAARs)}

The results in Panel A of Table 1 show that the CAARs are negative and statistically significant at a minimum $10 \%$ significance level for five event windows ${ }^{2}$. The CAARs from the six-month period is $-8.82 \%$, and this decreases gradually to $-18.62 \%$ by the third year ${ }^{3}$. This suggests that the emerged companies significantly underperform relative to the size-matched companies for the entire three-year window. The parallel median abnormal returns also display similar findings, further supporting the mean abnormal returns result. Furthermore, Panel B shows the results using the sample matched based on size and market-to-book value. The mean CAARs are all negative for all periods, but significant mean abnormal returns are reported for the sixmonth, one-year, 18-month and two-year periods. The average CAARs reported $-9.56 \%(p<$ $0.10)$ for the six-month period, $-11.16 \%(p<0.10)$ for the one-year period, $-14.74 \%(\mathrm{p}<0.05)$ for the 18-month period, and $-13.78 \%(p<0.10)$ for the two-year period. Using CAARs, these findings suggest that the emerged financially distressed companies experience abnormally negative returns when compared to companies sharing either a similar size or both a similar size and market-to-book value.

\footnotetext{
${ }^{2}$ Since most of the financially distressed companies in the sample trade at prices below RM1.00 per share, extreme outliers are taken into consideration by winsorizing the sample at the $1 \%$ level at both tails to reduce the impact of low-priced stocks on the skewness of ex-post returns (Kausar, Taffler and Tan, 2009).

${ }^{3}$ CAARs and BHARs using the EMAS index return and KLCI index return as the market return report similar results to those using the matching companies approach, although of larger magnitude. The results can be obtained upon request.
} 
Table 1. Sample description.

\begin{tabular}{lr}
\hline \hline Distribution by industry & \\
\hline Technology & 11 \\
Industrial Products & 29 \\
Trading/Services & 29 \\
Consumer Products & 7 \\
Construction & 12 \\
Properties & 16 \\
Plantations & 7 \\
Hotels & 1 \\
Infrastructure Project Company (IPC) & 2 \\
\hline Total & 114 \\
\hline \hline
\end{tabular}

Table 2. Cumulative average abnormal returns (CAARs).

\begin{tabular}{|c|c|c|c|c|}
\hline Event period & $\begin{array}{r}\text { Mean abnormal } \\
\text { returns }(\%)\end{array}$ & $t$-statistics & $\begin{array}{r}\text { Median abnormal } \\
\text { returns }(\%)\end{array}$ & $z$-statistics \\
\hline \multicolumn{5}{|c|}{ Panel A: Matched with size } \\
\hline 3 months & -0.56 & -0.1396 & -2.86 & -0.735 \\
\hline 6 months & -8.82 & $-1.9078 *$ & -11.50 & $-2.177 * *$ \\
\hline 1 year & -12.69 & $-1.9569 * *$ & -14.91 & $-2.036 * *$ \\
\hline 18 months & -16.67 & $-2.4241 * *$ & -18.63 & $-2.451 * * *$ \\
\hline 2 years & -19.94 & $-2.4323 * *$ & -20.62 & $-2.252 * *$ \\
\hline 3 years & -18.62 & $-1.7345^{*}$ & -20.78 & $-1.861 *$ \\
\hline \multicolumn{5}{|c|}{ Panel B: Matched with size and market-to-book value } \\
\hline 3 months & -3.36 & -0.8132 & -5.43 & -1.158 \\
\hline 6 months & -9.56 & $-1.8996 *$ & -9.93 & $2.388 * *$ \\
\hline 1 year & -11.16 & $-1.7518 *$ & -12.58 & $-2.302 * *$ \\
\hline 18 months & -14.74 & $-2.1068 * *$ & -20.58 & $-2.465 * * *$ \\
\hline 2 years & -13.78 & $-1.7773 *$ & -22.04 & $-1.927 * *$ \\
\hline 3 years & -7.77 & -0.8198 & -9.72 & -0.972 \\
\hline
\end{tabular}

Note: *,**,*** denote significance at the 10,5 and $1 \%$ level, respectively, using a two-tailed test. The Wilcoxon signed-rank test is used for the median.

The estimation results are indirectly compatible with the research of Hotchkiss (1995), who found that $40 \%$ of firms emerging from Chapter 11 continue to experience operating losses in the three years after emergence, and nearly a third of these firms require a second bankruptcy filing or distressed restructuring. In addition, Komera and Lukose (2013) demonstrate that 30\% of the companies continue to report negative operating performance in the post-bankruptcy period using a sample of listed companies in India. Moreover, our results are consistent with the findings of Hotchkiss and Mooradian (1997), Gilson (1997), and Komera and Lukose (2013). Komera and Lukose (2013) find that the mean returns range from $-28.41 \%$ to $-31.26 \%$ for up to 12 months after emergence from bankruptcy.

\subsection{Buy-and-hold abnormal returns (BHARs)}

The results in Panel A of Table 2 show that the BHARs are negative for all holding periods except for the three-month period, which is similar to the findings of the CAARs previously discussed in Table 1. The negative and significant BHARs of $-10.81 \%(p<0.05),-14.84 \%(p$ $<0.05),-17.80 \%(p<0.01),-24.24 \%(p<0.01)$ and $-30.33 \%(p<0.01)$ are produced in the six-month, one-year, 18-month, two-year and three-year holding periods, respectively. The bootstrapped skewness-adjusted $t$-statistics reaffirm the statistical significance of the standard cross-sectional $t$-test statistics. The results indicate that on average, investors who buy shares in emerged financially distressed companies in the month that these companies have been 
declared "healthy" and hold them for a three-year period will generate significant negative abnormal returns. Similarly, the corresponding median abnormal returns of five periods (except the three-month period) are negative and statistically significant.

Panel B shows the results of using the sample matched based on size and market-to-book value. The reported long-run underperformance is significant at a minimum $10 \%$ significance level for five holding periods. The highest underperformance of $-29.15 \%$ is found in the threeyear holding period. As can be observed, the BHARs and CAARs display similar patterns, with post-emergence performance declining over the three years after the companies have emerged on the Bursa Malaysia exchange. In conclusion, the returns are negative irrespective of the approach employed to calculate the abnormal returns and the matching procedure employed, although it is worth noting that the findings are moderately sensitive to the methodological approach employed.

Table 3. Buy-and-hold abnormal returns (BHARs).

\begin{tabular}{|c|c|c|c|c|}
\hline Event period & $\begin{array}{r}\text { Mean abnormal } \\
\text { returns }(\%)\end{array}$ & t-statistics & $\begin{array}{r}\text { Median abnormal } \\
\text { returns }(\%)\end{array}$ & z-statistics \\
\hline \multicolumn{5}{|c|}{ Panel A: Matched with size } \\
\hline 3 months & -3.10 & -0.8310 & -0.77 & -4.00 \\
\hline 6 months & -10.81 & $-2.3979 * *$ & $-2.14 * *$ & -11.74 \\
\hline 1 year & -14.84 & $-2.3728 * *$ & $-1.91 *$ & -16.70 \\
\hline 18 months & -17.80 & $-2.8534 * * *$ & $-2.49 * * *$ & -18.65 \\
\hline 2 years & -24.24 & $-3.5966 * * *$ & $-3.42 * * *$ & -23.33 \\
\hline 3 years & -30.33 & $-3.3924 * * *$ & $-2.96 * * *$ & -22.01 \\
\hline \multicolumn{5}{|c|}{ Panel B: Matched with size and market-to-book value } \\
\hline 3 months & -3.84 & -1.1052 & -1.02 & -6.51 \\
\hline 6 months & -8.93 & $-1.7903^{*}$ & -1.35 & -13.62 \\
\hline 1 year & -14.16 & $-2.5613 * * *$ & $-2.00 * *$ & -16.40 \\
\hline 18 months & -17.38 & $-2.9796^{* * *}$ & $-2.51 * * *$ & -27.12 \\
\hline 2 years & -17.56 & $-2.0381 * *$ & -1.49 & -19.48 \\
\hline 3 years & -29.15 & $-2.7410 * * *$ & $-2.70 * * *$ & -15.21 \\
\hline
\end{tabular}

Note: $* * *, * * *$ denote significance at the 10,5 and $1 \%$ level, respectively, using a two-tailed test. The Wilcoxon signed-rank test is used for the median.

\section{Conclusion}

This study examined whether firms emerging from a financially distressed condition outperform when compared to their counterparts. The evidence suggests that post-emergence performance declines over the three-year period. This implies that companies emerging from financial distress demonstrate unfavourable performance, even though they have been classified as "healthy" by the stock exchange regulator. The returns are negative irrespective of the approach to calculate the abnormal returns and the matching procedure employed. This shows that investors do not believe that the companies have successfully restructured their financial condition and, thus, do not consider the emerged companies in their investment portfolio. In this sense, attention should be given to these formerly financially distressed companies to determine the reasons for declining share price performance when companies have been allowed to continue to be listed following the restructuring process. Regulators should strengthen the evaluation process for financially distressed companies in determining if they are allowed to be relisted. In this sense, a fair avenue of investment could be better ensured. 


\section{References}

Alderson, M. J., and Betker, B. L. (1999) Assessing post-bankruptcy performance: An analysis of reorganized companies' cash flows, Financial Management, 28, 68-82.

Barber, B. M., and Lyon, J. D. (1997) Detecting long run abnormal stock returns: The empirical power and specification of test statistics, Journal of Financial Economics, 43, 341-372.

Campbell, R. D., Giambona, E., and Sirmans, C. F. (2009) The long-horizon performance of REIT mergers, The Journal of Real Estate Finance and Economics, 38, 105-114.

Eberhart, A. C., Altman, E. I., and Aggarwal, R. (1999) The equity performance of companies emerging from bankruptcy, Journal of Finance, 54, 1855-1868.

Gilson, S. C. (1997) Transactions costs and capital structure choice: Evidence from financially distressed companies, Journal of Finance, 52, 161-196.

Gompers, P. A., and Lerner, J. (2003) The really long-run performance of initial public offerings: The Pre-Nasdaq evidence, Journal of Finance, 58(4), 1355-1392.

Hotchkiss, E. S. (1995) Post-bankruptcy performance and management turnover, Journal of Finance, 50, 3-21.

Hotchkiss, E. S., and Mooradian, R. M. (1997) Vulture investors and the market for control of distressed companies, Journal of Financial Economics, 43, 401-432.

Jory, S. R., and Madura, J. (2010). The long-run performance of companies emerging from Chapter 11 bankruptcy, Applied Financial Economics, 20, 1145-1161.

Kausar, A., Taffler, R., and Tan, C. (2009) The going-concern market anomaly, Journal of Accounting Research, 47 (1): 213-239.

Komera, S., and Lukose, P. J. J. (2013) No longer sick: what does it convey? An empirical analysis of post-bankruptcy performance, International Journal of Emerging Markets, 8, 182-202.

Loughran, T., and Ritter, J. R. (2000) Uniformly least-powerful tests of market efficiency, Journal of Financial Economics, 55, 361-389. 